\title{
Does Sectarian Threat Weaken Support for Democracy in Egypt?
}

\author{
Alexandra Domike Blackman and Scott Williamson*
}

January 31, 2022

\begin{abstract}
Research indicates that concerns about political, social, and economic stability can undermine support for democracy. We extend this literature through a survey experiment implemented in Egypt that tests whether priming respondents on sectarian conflict in the country triggers more negative attitudes toward democracy by increasing perceptions of threat and disorder. Our study returned statistically insignificant results and if anything suggested that Egyptians primed on communal violence between Muslims and Christians became more supportive of democracy.
\end{abstract}

${ }^{*}$ Cornell University and Bocconi University. 


\section{Introduction}

Sectarian conflict between religious groups is common in the Middle East and elsewhere. Do concerns about sectarianism affect attitudes toward democracy? Research indicates that fears of political, social, and economic instability undermine support for democracy and make citizens more willing to accept authoritarian governance (Abadeer et al. 2022, Cammett et al. 2020; Hou and Quek 2018; Kethcley and El-Rayyes 2020). Similarly, we might expect that violence between religious groups makes individuals more likely to want an authoritarian government that enforces order with a strong hand to minimize conflict between these groups. ${ }^{1}$ For instance, during Egypt's troubled transition to democracy, increasing communal violence between Muslims and Christians played into narratives about the weakness of nascent democratic institutions. Since the transition's failure in 2013, the new dictator and his regime have emphasized unity between Muslims and Christians as part of their propaganda justifying their rule. At the same time, the regime has not prosecuted cases of communal violence and has permitted tensions between these communities to fester (Yerkes 2016).

Do such tensions benefit the regime and others like it? We implemented a survey experiment in March 2020 to analyze whether priming Egyptians on sectarian violence in the country increased support for authoritarian rule and weakened faith in democracy. The experiment produced null effects, and if anything the results provided weak evidence that the prime strengthened support for democracy instead. We report our null findings here based on the template suggested by Alrababa'h et al. (Forthcoming).

\section{Research Design}

The study was preregistered with OSF using the aspredictor.org template.

Sample: The survey was administered to a sample of 1,471 Egyptian adults recruited by Qualtrics from their pre-existing panel of Egyptian survey takers. The survey was representative on age and gender.

Study Design: Respondents were randomly assigned with equal probability to control and treatment groups. The control group proceeded straight to the mediation questions (see below). The treatment group read the following statement first: Violent attacks against Egyptian Christians have been common in recent years. Mobs have burned Christian homes, forced churches to close, and chased Christians out of their neighborhoods. A number of Christians have also been killed by armed assailants. Respondents then answered the mediation and outcome questions.

Hypotheses: We hypothesized that being primed on sectarian conflict would reduce support for democracy and increase support for strongman leadership / authoritarian governance. We also hypothesized that these effects would be mediated by increased concerns over Egypt's security and social stability. In addition, we expected that Christian respondents would be

\footnotetext{
${ }^{1}$ For those with primordialist views of sectarianism, this is one of the solutions to sectarian conflict that is sometimes proposed (Dixon 2018).
} 
more responsive to the prime than Muslim respondents, since they would be more threatened as the minority, and that individuals prejudiced toward religious out-group members would be less responsive.

Outcomes: We measured attitudes toward democracy through the following questions:

- Some feel that we should rely on a democratic form of government to solve our country's problems. Others feel that we should rely on a leader with a strong hand to solve our country's problems. Which comes closer to your opinion?

- How much do you agree or disagree with the following statements about democratic and authoritarian political systems?

- Democratic systems are ineffective at maintaining order and stability.

- Democratic governments are indecisive and full of problems.

- Under a democratic system, the country's economic performance is weak.

- In an authoritarian system, the government gets things done quickly and efficiently.

- Authoritarian regimes keep law-abiding citizens safe from violent criminals and political instability.

- On a scale of 1 to 10 , how important is it that you live in a democracy?

We used PCA to create an aggregated measure of attitudes toward democracy.

For the mediation analysis, we asked the following two questions:

- Do you agree or disagree that conflict between Muslims and Christians threatens Egypt's security?

- Do you agree or disagree that conflict between Muslims and Christians represents a form of social disorder or fitna?

\section{Results}

We report results in Table 1 below using OLS regressions. The coefficients for the sectarian treatment are insignificant. Contrary to expectations, Column 1 indicates that respondents primed on sectarian conflict in Egypt were somewhat more likely to express favorable attitudes toward democracy. Column 2 implies that this effect would be larger among Christians, also in the opposite direction from what we expected. ${ }^{2}$ Columns 3 and 4 show that the prime slightly increased perceptions that sectarian violence threatened security and order in Egypt, in line with our expectations, but these results just missed statistical significance at conventional levels.

\footnotetext{
${ }^{2}$ We also find no evidence that more prejudiced individuals responded differently to the treatment.
} 
Table 1: Results

\begin{tabular}{|c|c|c|c|c|}
\hline & $\begin{array}{c}(1) \\
\text { Democracy } \\
\text { PCA }\end{array}$ & $\begin{array}{c}(2) \\
\text { Democracy } \\
\text { PCA }\end{array}$ & $\begin{array}{c}(3) \\
\text { Conflict } \\
\text { Mediator }\end{array}$ & $\begin{array}{c}(4) \\
\text { Disorder } \\
\text { Mediator }\end{array}$ \\
\hline Sectarian Prime & $\begin{array}{c}0.142 \\
(0.103)\end{array}$ & $\begin{array}{c}0.440 \\
(0.452)\end{array}$ & $\begin{array}{c}0.226 \\
(0.116)\end{array}$ & $\begin{array}{c}0.207 \\
(0.108)\end{array}$ \\
\hline Muslim & & $\begin{array}{c}0.340 \\
(0.305)\end{array}$ & & \\
\hline Prime x Muslim & & $\begin{array}{l}-0.314 \\
(0.464)\end{array}$ & & \\
\hline Constant & $\begin{array}{l}-0.072 \\
(0.073)\end{array}$ & $\begin{array}{l}-0.391 \\
(0.300)\end{array}$ & $\begin{array}{c}4.893^{* * *} \\
(0.083)\end{array}$ & $\begin{array}{c}5.175^{* * *} \\
(0.077)\end{array}$ \\
\hline Observations & 1,453 & 1,453 & 1,469 & 1,469 \\
\hline
\end{tabular}

\section{Interpretation}

\subsection{Methodological Reasons}

Power: It seems likely that, if we had a larger sample, we would have found statistically significant effects indicating that priming sectarian tensions increased support for democracy.

Measurement: We used standard measures of support for democracy.

Treatment Design: Our results indicate that the sectarian conflict prime did not significantly increase the perception that sectarian violence threatened security and order. To improve the study, we could have used a stronger treatment with more details or an actual news article. However, this treatment likely would have produced effects in the opposite direction.

Spillover: We have no reason to believe that spillovers would be plausible in this study.

\subsection{Theoretical Reasons}

Blame for Violence: As expected, the prime seems to have slightly increased perceptions that sectarian violence threatened order and security in Egypt. Given that Egypt was governed by Al-Sisi's authoritarian regime at the time the study was implemented, one explanation for the unexpected direction of the results could be that respondents were blaming the regime for the communal violence and therefore became slightly more likely to prefer a different type of political system. 


\section{Implications and Next Steps}

In studying attitudes toward democracy and authoritarianism, a common thread is the idea that instability makes people more willing to accept repressive government as long as it can create order. While this may apply in political systems that are already democratic, an implication of our results is that people experiencing social conflict under an authoritarian government may become more supportive of democracy. This pattern would make sense if they hold their government responsible for failing to address the problem and believe that the situation would improve with a change of the political system. Our results were statistically insignificant, so no firm conclusions can be drawn; however, these ideas may be worth pursuing further with other research designs.

\section{Bibliography}

Abadeer, Caroline; Alexandra Blackman, Lisa Blaydes, and Scott Williamson. Forthcoming. "Did Egypt's Post-Uprising Crime Wave Increase Support for Authoritarian Rule?" Journal of Peace Research.

Alrababa'h, Ala'; Scott Williamson, Andrea Dillon, Dominik Hangartner, Jens Hainmueller, Michael Hotard, David Laitin, and Jeremy Weinstein. Forthcoming. "Learning from Null Effects: A Bottom-Up Approach." Political Analysis.

Cammett, Melani; Ishac Diwan, and Irina Vartanova. 2020. "Insecurity and political values in the Arab world." Democratization 27(5): 699-716.

Dixon, Paul. 2018. "Beyond Sectarianism in the Middle East?" In Beyond Sunni and Shia: The Roots of Sectarianism in a Changing Middle East, Frederic Wehrey, ed. Oxford: Oxford University Press, 11-36.

Hou, Yue and Kai Quek. 2018. "Violence Exposure and Support for State Use of Force in a Non-Democracy." Journal of Experimental Political Science 6 (2): 120-130.

Ketchley, Neil and Thoraya El-Rayyes. 2021. "Unpopular Protest: Mass Mobilization and Attitudes to Democracy in Post-Mubarak Egypt." The Journal of Politics 83 (1): 291-305.

Yerkes, Sarah. 2016. "What Egypt under Sissi is really like for Coptic Christians."

Brookings Institution. June 20. https://www.brookings.edu/blog/markaz/2016/ 06/20/what-egypt-under-sissi-is-really-like-for-coptic-christians/. 